\title{
In Vitro Toxicology, Biodetection and Risk Assessment
}

\author{
Benoît Schilter*, Karma Fussell, Julie Mollergues, Hélia Latado and Maricel Marin-Kuan \\ Chemical Food Safety group, Nestlé Research Center, Switzerland
}

Submission: March 08, 2018; Published: March 15, 2018

*Corresponding author: Benoît Schilter, Chemical Food Safety group, Nestlé Research Center, Lausanne, Switzerland, Email: benoit.schilter@rdls.nestle.com

\section{Opinion}

\section{Context}

Food may be assumed as a complex mixture of chemicals. Some are intrinsic components, including macro-and micronutrients, anti-nutrients and inherent toxicants, while others are extrinsic, either added or resulting from natural or industrial sources. In addition, process-related chemicals are formed during processing. To understand the health significance of food chemicals is complex. Many increase but others reduce nutritional value. Some may be associated with beneficial effects. A number have been shown to be harmful, producing toxicity. Therefore, chemicals must be managed to ensure that food is safe. Risk assessment, combining exposure and toxicological information, has been valuable to identify chemicals of concern on which management efforts should focus. Toxicological characterization is a resource-intensive and time-consuming process based on feeding experimental animals with high doses of the chemical investigated. Only a limited number of chemicals have been fully tested; for the vast majority of compounds to which humans are exposed, no data is available [1]. This raises the question of how to establish the safety of the numerous toxicologically uncharacterized chemicals.

\section{In vitro toxicology and hazard characterization}

Currently the application of the standard toxicology approach to all known but untested chemicals is increasingly questioned from scientific, feasibility and ethical perspectives. The field of experimental toxicology is currently undergoing a major shift, moving from high dose animal studies towards more mechanistic and human relevant approaches. This is illustrated by large research initiatives such as Tox21, which combines the use of hundreds of in vitro assays with computational modelling [2]. In this framework, the concept of Adverse Outcome Pathways (AOPs) is acknowledged as a way to organize mechanistic information to be applied in risk assessment [3]. In the AOP concept, Molecular Initiating Events (MIE) are linked through pathways/networks of key events to adverse effects. The application of in vitro toxicology in such a context may require the use of human relevant cell systems adequately reflecting organ/tissue diversity and structural complexity together with the application of integrative modelling approaches according to system toxicology [4]. In addition chemical biotransformation must be considered. One of the additional challenges is the suitability of the test systems to cover the most important AOPs. This may be solved through the development of high-throughput toxicogenomic methods. To exploit the data in a context of risk assessment requires translation of in vitro concentrations into in vivo external doses which can be benchmarked against exposure estimates. Currently, methods based on determination of free concentration of the tested chemicals together with physiologically-based biokinetic modelling allow such in vitro to in vivo extrapolations (IVIVE) [2].

\section{Biodetection}

The increasing mechanistic understanding of toxic action and its translation into AOPs have triggered the development of cell culture-based systems (bioassays, biotests) to detect bioactivities relevant in term of MIEs and key events. These test systems are not designed to reflect normal human cells/ tissues, but have been constructed to optimize the detection of targeted biological activities (e.g. estrogen receptor activation, DNA-damage) $[5,6]$. They can be seen as bringing an analytical detection principle that is alternative to the usual physicochemical ones. Application of bioassays to pure chemicals provides insight into their intrinsic biological properties; in chemically uncharacterized mixtures, they highlight the presence of substance(s) associated with a particular activity. Biodetection systems have been successfully applied in many situations, such has for biopharmaceutical quality assurance, for assessment of medical devices and in environmental monitoring, e.g. water. They can significantly contribute to research and development to design intrinsically safe chemicals (green chemistry). They have been recently promoted as playing a potential role in the safety assessment of food packaging materials. The main strength of the application of 
bioassays is to establish priorities through early identification of chemicals of potential concern. In combination with analytics, relevant chemicals can be identified (effect-directedanalyses). Bioassays may also provide information on potential combined effects of chemicals in mixtures. With regards to risk assessment, bioassay data are rarely usable as such. In general, they must be anchored to more traditional analytical and toxicological information, or to in silico predictions for effective use in this context. For example effect-directed analysis may facilitate the identification and quantification of toxicologically relevant chemicals in a mixture. However, to address their safety significance, exposure must be estimated and compared to toxicological data suitable for hazard characterization [7]. Chemical grouping and read-across are increasingly recognized as an in silico methods to predict toxicological values usable for a risk assessment framework (to establish level of safety concern) [8]. This process consists of identifying analogs of the chemical under investigation (grouping) and extrapolating its toxic properties using toxicological data available for the analogues (read-across). Finding adequate analogs is not straightforward and cannot rely only on structural features. Bioassay data will likely play an increasing role in the definition of chemical analogs. In the case of exposure to a number of structurally similar chemicals, bioassay data may also be valuable to get insight on the need to apply principles of mixture toxicology for assessing risk [9].

\section{Summary and Conclusion}

There is a recognized need to characterize the toxicological properties of a high number of chemicals to which humans are exposed. It is increasingly acknowledged that this cannot be achieved by applying a traditional approach based on toxicological studies in experimental animals. In vitro toxicology is thought to be an alternative approach which will play an increasingly important role for hazard characterization and risk assessment, bringing potentially more mechanistic and relevant information for the human situation. In vitro and molecular toxicology have triggered the development of molecular- and cell-based biological tools (biodetectors) designed to detect activities at specific targets. There are numerous potential applications; however, to serve risk assessment, biodetection data should in general be anchored to analytical and toxicological information.

\section{References}

1. Fowler B, Savage S, Mendez B (2011) Protecting public health in the $21^{\text {st }}$ century: the case of computational toxicology. White paper, ICF International, USA.

2. Judson R, Houck K, Martin M, Knudsen T, Thomas RS, et al. (2014) In vitro and modelling approaches to risk assessment from the U.S. Environmental Protection agency ToxCast Programme. Basic Clin Pharmacol Toxicol 115(1): 69-76.

3. OECD (2013) Guidance document on developing and assessing adverse outcome pathways. Health and Safety Publication Series on testing and Assessment No 184.

4. Bal-Price A, Crofton KM, Leist M, Allen S, Arand M, et al. (2015) International Stakeholder NETwork (ISNET): creating a developmental neurotoxicity (DNT) testing road map for regulatory purposes. Arch Toxicol 89(2): 269-287.

5. Van der Burg B, Winter R, Weiner M, Berckmans P, Suzuki G, et al. (2001) Optimization and pre validation of the in vitro ERalpha CALUX method to test estrogenic and antestrogenic activity of compounds. Reprod Toxicol 30(1): 73-80.

6. Knight AW, Little S, Houck K, Dix D, Judson R, et al. (2009) Evaluation of high-throughput genotoxicity assays used in profiling the US EPA Tox Cast chemicals. Regul Toxicol Pharmacol 55(2): 188-199.

7. Veyrand J, Marin-Kuan M, Bezençon C, Frank N, Guérin V, et al. (2017) Integrating bioassays and analytical chemistry as improved approach to support safety assessment of food contact materials. Food Addit Contam Part A Chem Anal Control Expo Risk Assess 34(10): 18071816.

8. Schilter B, Benigni R, Boobis A, Chiodini A, Cockburn A, et al. (2014) Establishing the level of safety concern for chemicals in food without the need for toxicity testing. Regul Toxicol Pharmacol 68(2): 275-296.

9. Ehrlich VA, Dellafiora L, Mollergues J, Dall'Asta C, Serrant P, et al. (2015) Hazard assessment through hybrid in vitro/in silico approach: the case of zearalenone. ALTEX 32(4): 275-286.

\section{Your next submission with Juniper Publishers will reach you the below assets}

- Quality Editorial service

- Swift Peer Review

- Reprints availability

- E-prints Service

- Manuscript Podcast for convenient understanding

- Global attainment for your research

- Manuscript accessibility in different formats ( Pdf, E-pub, Full Text, Audio)

- Unceasing customer service

Track the below URL for one-step submission https://juniperpublishers.com/online-submission.php 